University of Nebraska - Lincoln

DigitalCommons@University of Nebraska - Lincoln

USGS Staff -- Published Research

US Geological Survey

2009

\title{
A robust, multisite Holocene history of drift ice off northern Iceland: implications for North Atlantic climate
}

John T. Andrews

University of Colorado, john.t.andrews@colorado.edu

Dennis Darby

Old Dominion University

Dennis Eberle

US Geological Survey

Anne E. Jennings

University of Colorado

Matthias Moros

Baltic Sea Research Institute

See next page for additional authors

Follow this and additional works at: http://digitalcommons.unl.edu/usgsstaffpub

Part of the Geology Commons, Oceanography and Atmospheric Sciences and Meteorology Commons, Other Earth Sciences Commons, and the Other Environmental Sciences Commons

Andrews, John T.; Darby, Dennis; Eberle, Dennis; Jennings, Anne E.; Moros, Matthias; and Ogilvie, Astrid, "A robust, multisite Holocene history of drift ice off northern Iceland: implications for North Atlantic climate" (2009). USGS Staff -- Published Research. 909.

http:// digitalcommons.unl.edu/usgsstaffpub/909 
Authors

John T. Andrews, Dennis Darby, Dennis Eberle, Anne E. Jennings, Matthias Moros, and Astrid Ogilvie 


\title{
A robust, multisite Holocene history of drift ice off northern Iceland: implications for North Atlantic climate
}

\author{
John T. Andrews, ${ }^{1 *}$ Dennis Darby, ${ }^{2}$ Dennis Eberle, ${ }^{3}$ Anne E. \\ Jennings, ${ }^{1}$ Matthias Moros ${ }^{4,5}$ and Astrid Ogilvie ${ }^{6}$
}

\author{
( ${ }^{1}$ INSTAAR and Department of Geological Sciences, University of Colorado, Box 450, Boulder CO \\ 80303, USA; ' Department of Ocean, Earth and Atmospheric Sciences, Old Dominion University, \\ Norfolk VA 23529, USA; ${ }^{3}$ US Geological Survey, 3215 Marine Street, Suite E-127, Boulder CO 80303, \\ USA; ${ }^{4}$ Bjerknes Centre for Climate Research, Allegaten 55, 5007 Bergen, Norway; ${ }^{5}$ Baltic Sea \\ Research Institute, Seestrasse 15, 18119 Rostock, Germany; ${ }^{6}$ INSTAAR and Department of \\ Anthropology, University of Colorado, Box 450, Boulder CO 80303, USA)
}

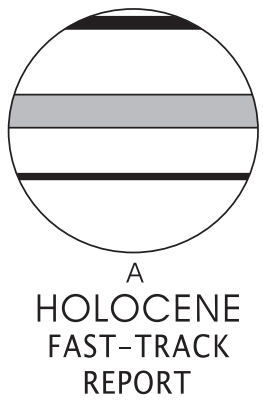

\section{Introduction}

We present a multisite proxy for drift-ice variations around Iceland (Figure 1) based on quantitative x-ray diffraction (XRD) analysis of the $<2 \mathrm{~mm}$ sediment fraction (usually $>99.9 \%$ of the total sediment) and thus expand on the results from MD99-2269 (Figure 2; Supplementary material available online) (Moros et al., 2006). As argued by Alley (2003) there is a need to replicate palaeoceanographic studies to test the robustness of conclusions reached from analysis of a single core. Drift ice is brought to Iceland in the East Iceland Current, an outer branch of the East Greenland Current, which exports sediment-laden sea ice from the Arctic Ocean through Fram Strait (Figure 1), or icebergs from the various east Greenland tidewater outlet glaciers. The bulk of the ice-transported sediment is in the silt and clay-size fractions (Hebbeln, 2000; Lisitzin, 2002), hence conventional protocols for defining ice-rafted debris (IRD), which are based on the sand fraction, will underestimate the total IRD contribution. The sea ice also carries driftwood from Russian and NW North American sources (Tremblay et al., 1997); abundant driftwood is stranded on

*Author for correspondence (e-mail: john.t.andrews@colorado.edu)
Icelandic beaches and originates from areas inland from the Kara and Barents seas (Figure 1) (Eggertsson, 1993).

Climate modelling indicates that variations in the extent of Northern Hemisphere sea ice have a major impact on the climate system (Parkinson, 2000; Smith et al., 2003), especially on winter temperatures. Variations in drift-ice trajectories are associated with the atmospheric forcing associated with the North Atlantic or Arctic oscillations (NAO, AO) (Tremblay et al., 1997; Parkinson, 2000), hence variations in a drift-ice proxy have the potential to illuminate decadal- to millennium-scale shifts in oceanographic and atmospheric circulations. The indexes for the NAO and AO are linked but not identical. During a positive AO (warm) phase the atmospheric circulation is essentially zonal and although sea ice is exported through Fram Strait it tends to be re-circulated into the Greenland Sea. In the negative (cold) phase the circulation is more meridional (Lamb, 1979) with a blocking ridge over Greenland and a trough boundary along East Greenland. This configuration is ideal for the export of sea ice as far south as Iceland and the Faeroe Islands (Figure 1).

Periods of extensive drift ice around Iceland result from the export of fresh water from the Arctic Basin (as sea ice) and Greenland Ice Sheet (as icebergs). This was documented in AD 


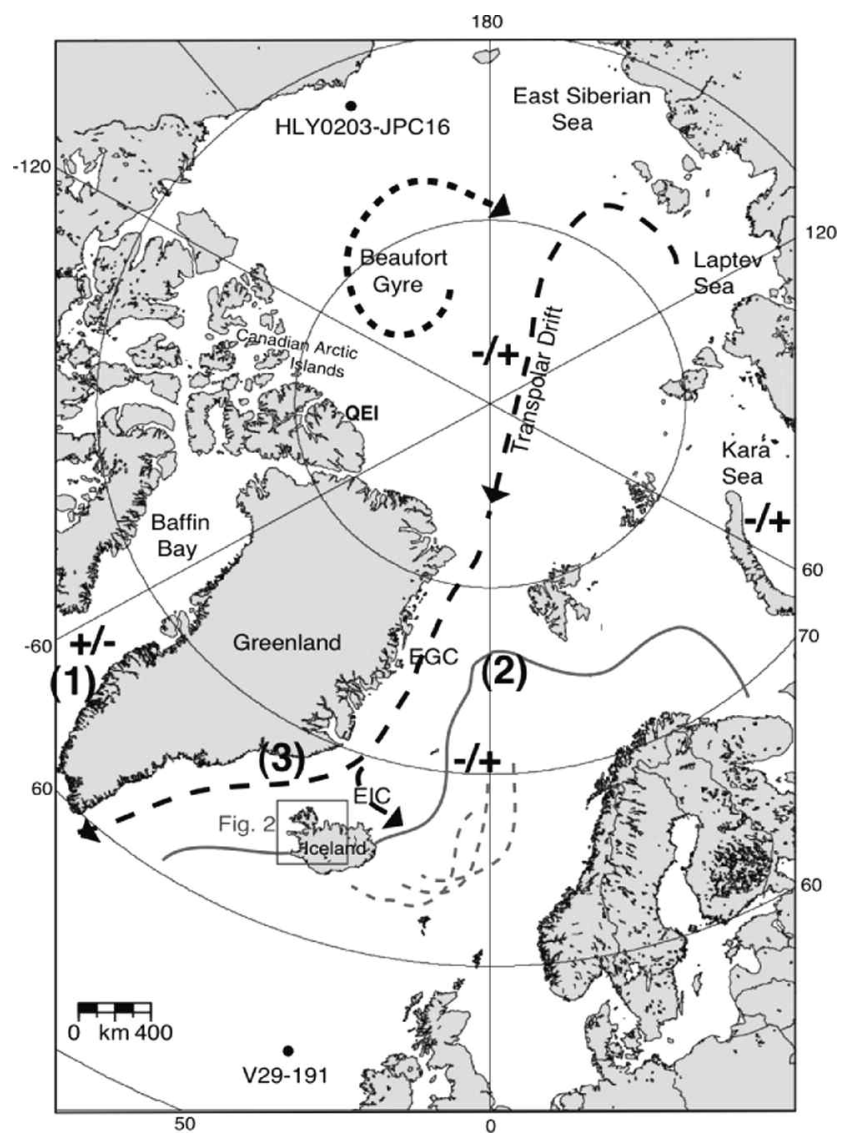

Figure 1 Major surface currents exporting drift ice toward Iceland Present-day extreme limit of the ice-edge (30\% ice concentration) and historical ice limits (after Lamb, 1979; Parkinson, 2000). QEI, Queen Elizabeth Islands; EGC, East Greenland Current; EIC, East Iceland Current; Core V29-191 (see text). The + and - signs refer to the trend in sea ice extent for 1979-1990 versus 1990-1999 (Parkinson, 2000). Numbers (1), (2), and (3) refer to areas mentioned in the text

1969 by the Great Salinity Anomaly (GSA) (Dickson et al., 1988), which led to the cessation of the formation of Labrador Sea deep water, a component of North Atlantic Deep Water. During the GSA the AO and the NAO achieved record negative values and ice invaded Iceland waters. When drift ice reaches the Iceland coast (usually in late winter/spring) it has a profound impact on both agriculture and fisheries (Ogilvie and Jonsdottir, 2000) because of the associated lowering of air and ocean temperatures (Jennings et al., 2001).

A major problem in palaeoclimate research is that of extending multiyear climate oscillations, detected from observational data, to the longer timescales that palaeostudies commonly deal with. By analogy we can imply positive or negative NAO- or AO-like conditions because of changes in our proxies, but how does the climate system maintain a multidecadal or centurylong mode?

The 'gold standard' for Holocene drift-ice variations in the North Atlantic, and indeed for Holocene climatic variability, is the stacked haematite-stained quartz counts (HSQ) (Bond et al., 2001), which appear to show a pervasive signal. A key site, V29191, lies well south of the historic ice edge limits (Figure 1) and well east of the present-day iceberg limit (Bigg et al., 1996), although the extreme historic limit of recorded growlers and bergy bits (International Ice Patrol) lies close to V29-191. However, other authors argued for significant regional variability in Holocene drift-ice histories (Moros et al., 2004; Andrews et al., 2006; Fisher et al., 2006).

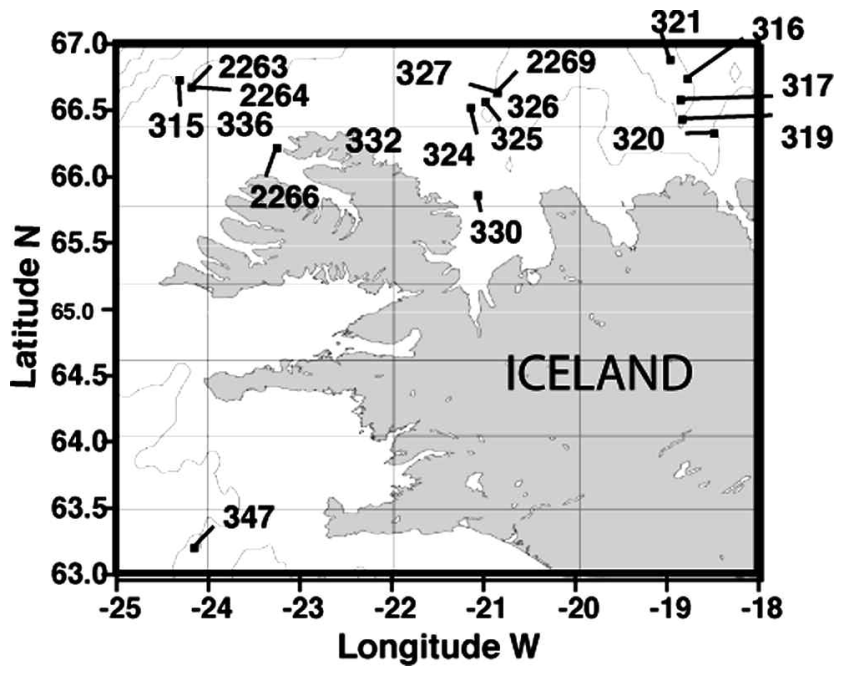

Figure 2 Core sites for MD99-2263, -2264 and -2269; all the other sites are from cruise B997-. Fe-oxide data on seafloor samples were obtained from B997-326, -323, -336, -332, -321 and -316

\section{Methods and data}

Our findings build on the results of quantitative XRD of the $<2 \mathrm{~mm}$ sediment fraction from core MD99-2269 (Table 1, Figure 2) (Moros et al., 2006), which has one of the best-dated Holocene records in the North Atlantic (Stoner et al., 2007). However, we agree with Alley (2003) that several cores from a region are required to fully substantiate a proxy record. The replication of results is especially important when there are reasons to expect that the proxy signal, in this case IRD, has the potential to be spatially and temporally variable (ie, noisy) because of changes in sediment entrainment, transport and melt (Warren, 1992; Bischof, 2000). It is also important to note that whereas the volume of ice calved per year from east Greenland tidewater outlet glaciers is of the order of tens of cubic kilometres per year, the flux of sea ice exiting the Arctic Ocean via the East Greenland Current (Figure 1) is two orders of magnitude more ( 2000-5000 km³/yr) (Foldvik et al., 1988).

The cored sediments on the Iceland shelf are principally clayey silts to sandy silts. Some 1665 samples from seafloor samples and from 15 cores (Table 1) were run on a D5000 Siemens x-ray diffraction (XRD) unit and processed through 'RockJock' (Eberl, 2003, 2004), identifying 18 non-clay and seven clay mineral species (see Andrews and Eberl, 2007 for additional information). This quantitative XRD method was placed third in the International Reynolds Cup competition (McCarty, 2002) for predicting a series of 'unknown' mineral mixtures; a third place finish was also awarded in 2008.

The clay minerals, volcanic glass, and calcite were excluded (this amounted to $56 \pm 10 \mathrm{wt} . \%$ ), and the data were then normalized to sum to $100 \%$. In Iceland waters calcite is a measure of marine productivity (on average $13 \mathrm{wt} . \%)$, and volcanic glass $(\sim 30$ wt.\% of the sediment on average) is added mainly by air fall and reworking; the clay minerals are difficult to ascribe to a source(s). The identified non-clay minerals included quartz, k-feldspars, plagioclase, dolomite, amphibole, pyroxene, pyrite, haematite and magnetite. Principal Component Analysis of the surface samples indicated that quartz, k-feldspar and dolomite are strongly associated with the first PC axis whereas plagioclase and pyroxene are located at the opposite end of the axis (Andrews and Eberl, 2007: figure 7). Quartz and potassium feldspar are essentially absent in the native Icelandic bedrock and the presence of quartz is used as a proxy for IRD (Moros et al., 2006). Replicate analyses indicate that the fractional error (standard deviation/mean) for quartz is \pm 
Table 1 Data on cores used in this study (see Figure 2)

\begin{tabular}{|c|c|c|c|c|c|c|}
\hline & Number dates & Core length (m) & Basal date & Top date & Number samples & Average/yr sample \\
\hline \multicolumn{7}{|l|}{ NW Iceland } \\
\hline B997-315 a & 5 & 2.49 & 12420 & 2760 & 92 & 105 \\
\hline MD99-2264 & 6 & $11.45^{\mathrm{b}}$ & 11850 & 1155 & 104 & 103 \\
\hline MD99-2263 ${ }^{\text {a }}$ & 5 & 0.46 & 1865 & -50 & 46 & 42 \\
\hline \multicolumn{7}{|l|}{ N Iceland } \\
\hline B99-322 & 4 & 0.5 & 14600 & 980 & 9 & \\
\hline B997-323 & 3 & 1 & $\sim 15000$ & 650 & 22 & \\
\hline B997-324 & 17 & 2.89 & 12300 & 150 & 107 & 114 \\
\hline B997-325 & 10 & 2.71 & 11610 & -50 & 85 & 137 \\
\hline B997-327 & 5 & 3.29 & 4340 & 310 & 63 & 64 \\
\hline MD99-2269 & 32 & 25.3 & 11860 & -50 & 413 & 29 \\
\hline B997-330 & 9 & 5.4 & 10970 & -50 & 108 & 102 \\
\hline B997-321 & 8 & 2.9 & 6160 & 355 & 62 & 94 \\
\hline B997-316 & 3 & 2.81 & 1335 & -50 & 53 & 26 \\
\hline B997-319 & 13 & 2.27 & 8950 & 175 & 69 & 127 \\
\hline B997-320 & 6 & 3.27 & 3400 & -50 & 59 & 58 \\
\hline \multicolumn{7}{|l|}{ SW Iceland } \\
\hline B997-347 & 8 & 4.8 & 12220 & 450 & 166 & 71 \\
\hline MD99-2266 & 26 & 37.6 & 10825 & 400 & 175 & 60 \\
\hline
\end{tabular}

${ }^{\text {a }}$ Unpublished data

${ }^{\mathrm{b}}$ Holocene length

0.08. Quartz and potassium feldspar are entrained into sea ice on the broad, shallow shelves of the Arctic Ocean (Lisitzin, 2002), or by glacial erosion and entrainment by calving outlet glaciers on East Greenland, the Queen Elizabeth Islands (QEI) (Figure 1), Svalbard and the Russian Arctic islands. Dolomite is principally contributed from the Palaeozoic outcrops in the southern QEI (Figure 1). For simplicity's sake we henceforth restrict our attention to variations in quartz wt.\%, which is commonly accepted as an IRD proxy in Iceland marine sediments (Eiriksson et al., 2000).

As quartz is not a specific provenance indicator we sought information on source areas through a pilot programme that involved the analysis of Fe-oxides (Darby and Bischoff, 1996). Fe oxide mineral grains from cores B997-321 and -316 (Table 1, Figure 2) (12 and 19 samples, respectively) were separated using a Frantz magnetic separator and a hand magnet, analysed by a microprobe for 12 elements, and the elements matched to the circum-Arctic source data base (Darby, 2003). Surface samples from five nearshore Iceland sites (Figure 2) were analysed in order to characterize $\mathrm{Fe}$ grains from Iceland; there is however an absence of $\mathrm{Fe}$ oxide data from the NE Greenland shelf, upstream from our field area (Figure 1), a potential source area for IRD.

Age control is based on ${ }^{14} \mathrm{C}$ AMS dates calibrated using CALIB 5 with a $\Delta R$ of 0 (Stuiver et al., 1998). Age/depth relationships have been published for all the cores except B997-315PC and MD99-2263 (Table 1). Some loss of temporal resolution can be expected because of bioturbation, and there are errors inherent in deriving interpolated age estimates (Andrews et al., 1999; Telford et al., 2003). Because of the storminess in this area (Dawson et al., 2003), and the occurrence of shallow banks on the flanks of the troughs from where the cores were collected, some sediment redistribution is expected and may indeed have an important climate signal (Andresen et al., 2005). The sampling interval varied from $\sim 20$ to $100-\mathrm{yr} /$ sample although coarser in two cores $(-322$ and -323), which were omitted.

A multisite study of any proxy is required to distinguish between regional long-term trends and the unique characteristics of any single site. In order to obtain an evenly dated, multisite record AnalySeries (Paillard et al., 1996) was used to integrate each record and derive quartz wt. $\%$ at 250 -yr intervals, from -0.05 to 11.7 cal. ka BP (Figure 3A) (see Supplementary materal online). The correlation between the original quartz wt.\% records and the 250-yr estimates was invariably $r>0.9$ indicating little loss of information. We chose 250 -yr as a somewhat conservative sample interval (Table 1) for the integration between AMS radiocarbon-dated levels. We hypothesize that if there were no coherent regional IRD signal then the resulting time series would have fluctuations no different than could arise by chance.

\section{Results}

Sediments on the north Iceland shelf contain virtually no grains $>2$ $\mathrm{mm}$ that can be attributed to the melting of icebergs. Thus they differ substantially from Holocene sediments on the East Greenland shelf, which are frequently stony diamictons with a large number of clasts $>2 \mathrm{~mm}$ (Andrews et al., 1997; Jennings et al., 2002). In seafloor samples, quartz is present on the outer to mid shelf in a band from NW Iceland to the limit of our sampling at $18^{\circ} \mathrm{W}$ (Moros et al., 2006; Andrews and Eberl, 2007: figure 4). Cores located close to land show zero or trace amounts of quartz whereas higher amounts of quartz wt.\% are recorded in the more northern sites. B997-347 (Figure 2) from SW Iceland is at the extreme limit of drift ice during extremely severe ice years (Ogilvie, 2005) and showed only intermittent trace amounts of quartz

Figure 3B shows the median quartz wt.\% distribution - this record is similar $(r=0.84)$ to the high-resolution $30 \mathrm{yr} / \mathrm{sample}$ quartz wt.\% data from MD99-2269 (Figures 2 and 4A) (Moros et al., 2006). The fact that our multicore record captures most of the lower frequency variations in MD99-2269 (Figure 4A) justifies the analysis of this core to provide a very high-resolution archive of Holocene environmental variability (eg, Andrews et al., 2003; Moros et al., 2006; Stoner et al., 2007) for an area affected by variations in the advection of Atlantic versus Arctic/Polar water masses (eg, Dickson et al., 1988). The time series of median quartz wt.\% data is 'robust' in the sense that the estimate is not influenced by extreme values (Velleman and Hoaglin, 1981). We 


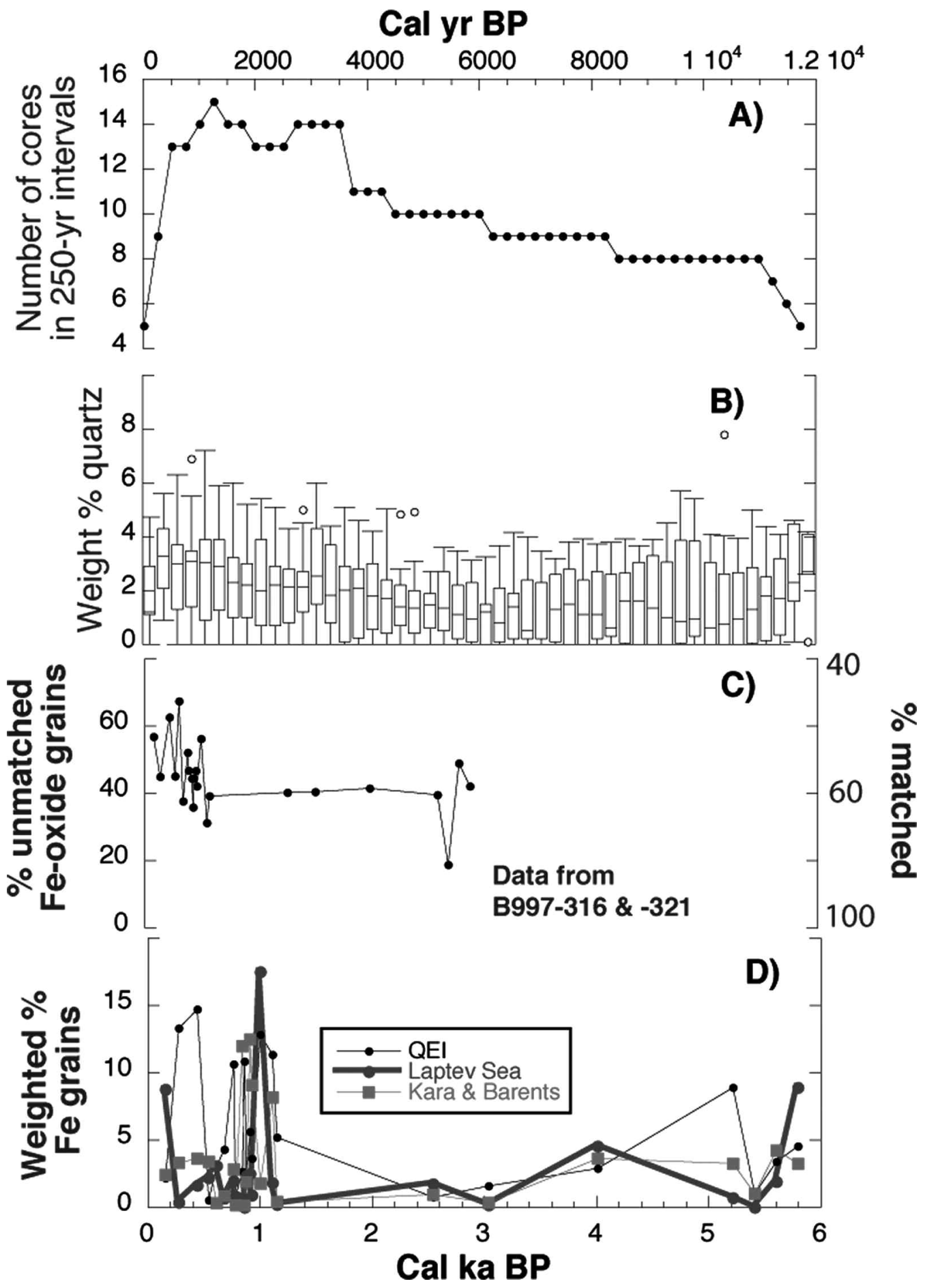

Figure 3 (A) The number of cores whose records are included in (B) at 250-yr increments. (B) Box plot of quartz wt.\% for nine non-clay minerals showing the inner $50 \%$ of the sample distribution for each 250 -yr increment. The small circles represent statistical outliers. (C) Plot of the \%unmatched Fe oxide data from B997-316 and -321. (D) Plot of the percent changes in Fe-oxides from cores B997-316 and -321 (Figure 2) in inputs from the Laptev, Kara and Barents seas, and the QEI (Figure 1)

tested the null hypothesis that the variations in the 250 -yr median quartz wt.\% are no different than might be expected by chance; the Runs Test rejected the null hypothesis $(z=-5.8, p>0.000)$ (Miller and Kahn, 1962). The null hypothesis was still rejected $(p \leq 0.04)$ after removal of the low-frequency temporal trend by application of a second degree polynomial.

At the beginning of the Holocene, quartz was reaching Iceland in significant amounts; median values steadily declined between 11.7 and $10.95 \mathrm{cal}$. ka BP and then had two peaks in input prior to reaching a minimum at $\sim 7 \mathrm{cal}$. ka BP. Marine temperature reconstructions
(Smith et al., 2005) indicated warmer conditions between 6 and 10 cal. ka BP. We attribute the early-Holocene high quartz wt.\% in part to the delivery by icebergs from the northern margins of the Laurentide and Innuitian ice sheets (Dyke, 2004), via Fram Strait (Figure 1). This assertion is supported by the presence of dolomite in early-Holocene and late-Pleistocene sediments on the Iceland shelf and slope (Andrews, 2008). This period of high IRD occurred during an interval of warmer conditions (Smith et al., 2005). Over the last 5-6 cal. ka BP, an interval when water temperatures were decreasing (Smith et al., 2005), quartz wt.\% 

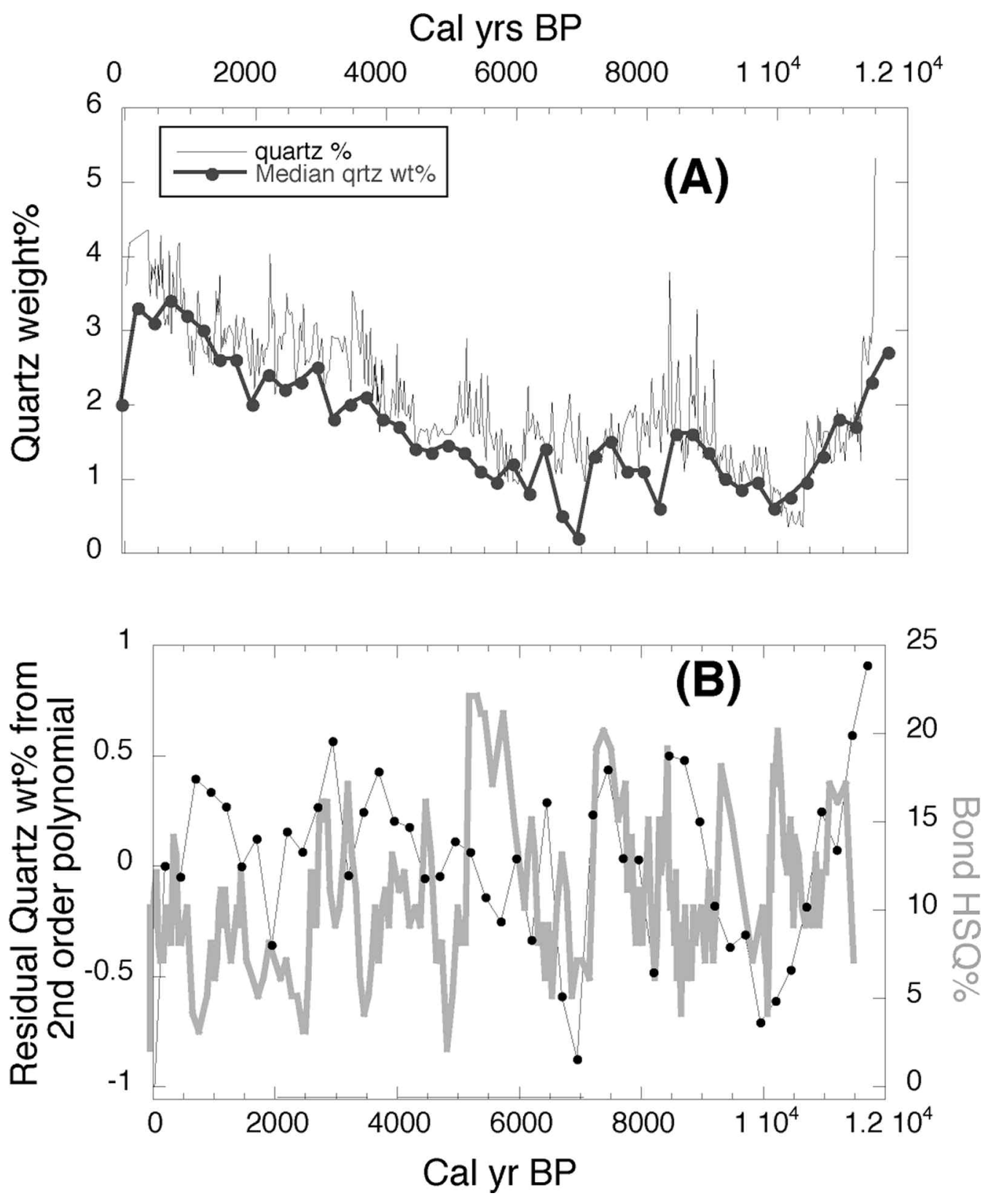

Figure 4 (A) Comparison of the median quartz data from this paper and the MD99-2269 30 yr resolution data (Moros et al., 2006). (B) Comparison of the haematite-stained quartz data from VM29-191 (Figure 1) (Bond et al., 2001) with the residuals from a second order polynomial on the median quartz wt.\% data (Figure 3B). The correlation between these two records is only 0.01

delivery to the Iceland margin increased, indicating an increase in sediment-laden ice. A jump in quartz wt. $\%$ at $\sim 2$ cal. ka BP (Figure 3B) correlates with the re-appearance of the 'glacial' benthic foraminifera Elphidium excavatum $\mathrm{f}$ clavata in north Iceland waters (Moros et al., 2006). Quartz wt.\% reached a Holocene maximum $c$. AD 1800 , about the time when the historical sea-ice index for Iceland reached its highest values (AD 1835) (Ogilvie, 1996). Multicentury- and millennial-scale oscillations are superimposed on this U-shaped record, which are more obvious if the overall trend is removed (Figure 4B). A single significant periodicity of $\sim 670 \mathrm{yr}$ was identified using the multiple taper method (MTM) (Weedon, 2005) on the residual data (Figure 4B).

An average of 65 Fe oxide grains $(0-189)$ were obtained from the samples from cores 321 and 316 (Figure 2); on average 35 grains per sample were matched to a specific source region. The percentage of unmatched grains varied between $\sim 15$ and $70 \%$ (Figure $3 \mathrm{C}$ ) and can be attributed in part to an absence in the data base of samples from the $\mathrm{E}$ and NE Greenland margins. Of the matched samples, most are from Iceland, however, two of the samples dated $\sim 1$ cal. ka BP from core 316 (Figure 3D) contained a majority of Fe grains from the QEI and the Laptev Sea (Figure 1). Both these sources are important elements in modern Arctic Ocean sea-ice (Darby, 2003). At $c .1$ cal. ka BP, Fe grains from the Kara Sea (15\%) and the East Siberian Sea (20\%) further emphasize this interval of influx of sea ice from the Arctic Ocean. A smaller influx of $\mathrm{Fe}$ oxide grains from the QEI occurs at $270 \mathrm{cal}$. yr BP. Consideration of the atmospheric modes required to entrain IRD from the Laptev Sea and the QEI and deliver these through Fram Strait to Iceland suggests that a key element is a switch from a positive to a negative NAO/AO mode; in isolation, neither mode can explain the data (Figure 3D). The large peak of Fe grains at about 1 cal. ka BP, coincides with the a large peak in $\mathrm{Fe}$ grains from Russian sources in core P1/B3 northwest of Alaska at the edge of the Chukchi Shelf that is linked to a strong positive AOlike climate mode (Darby and Bischof, 2004). 


\section{Conclusions}

We present a quantitative, highly reproducible, stacked record from 16 cores around Iceland of the quartz wt. $\%$ in the $<2 \mathrm{~mm}$ sediment fraction. The presence of quartz throughout the Holocene demonstrates that on multicentury timescales, drift ice has rarely been absent from this region. Especially over the last 5 cal. ka BP, drift ice, most probably sea ice, has been pervasive. Thus on these timescales the North Atlantic circulation mode has probably been more meridional than zonal, implying a dominance of negative NAO-like conditions. IRD records from areas 1 and 2 in the North Atlantic (Figure 1) (Andrews et al., 2006) are distinctly different from the north Iceland record, which is however similar to area 3 (East Greenland) (Andrews et al., 1997; Jennings et al., 2002), hence Holocene drift-ice proxies show regional variability (Moros et al., 2004, 2006; Fisher et al., 2006) rather than a single pervasive pattern (Bond et al., 2001).

We do not detect a $\sim 1500$ yr periodicity in the quartz IRD, rather our multicentury-scale data show a $\sim 670$ yr periodicity. However, MTM analysis of the detrended high resolution data from MD992269 (Moros et al., 2006) (Figure 4A) indicates several significant periodicties $(p \geq 0.95)$ between 87 and $61 \mathrm{yr}$, reminiscent of the multidecadal Atlantic oscillation (Kerr, 2005). Our data bear little similarity to the HSQ data at VM129-191 (Bond et al., 2001) (Figure 4B). Our sites are from a region that is clearly affected by drift ice (Figure 1) and lies at a boundary between Atlantic and Arctic/Polar water masses (Dickson et al., 1988). In contrast the HSQ data from VM29-191 is from an area within the regime of the North Atlantic Current (Moros et al., 2006), hence the delivery of a coherent IRD signal to the site is problematical and indeed unlikely.

We cannot as yet fully answer the question: what were the specific source areas for the drift ice that brought quartz to Iceland waters throughout the Holocene? The intermittent presence of dolomite throughout the Holocene (Andrews and Eberl, 2007) indicates the transport of sediment in drift ice, probably from Palaeozoic outcrops in the Canadian Arctic islands and channels. However, a major change occurred $\sim 1$ cal. ka BP when iron-oxide grains from a variety of sources around the Arctic Ocean reached Iceland. This may be associated with an intensification of a positive AO-like climate mode. An expansion of our pilot programme (Figure 3D), and an expansion of the Fe-oxide data base to NE and $\mathrm{E}$ Greenland sites is required to gain a better understanding of the sources of drift ice in Iceland waters on Holocene timescales.

\section{Acknowledgements}

Research carried out under NSF-OPP 0326776 and ATM-0502515. Undergraduates G. Diefenbach and C. Coleman processed the samples for cores B997-347 and MD99-2264, respectively. Moros ran the samples from MD99-2269; Andrews processed the rest. Fe grain fingerprinting was conducted with NSF support (OPP-0550109 and -0612493). Astrid Ogilvie is supported by NSF-OPP-0629500 and by RANNÍS. Drs R.S. Bradley and M. Kirby commented on earlier drafts of the manuscript. We acknowledge the input of reviewers whose comments resulted in an improved manuscript.

\section{References}

Alley, R.B. 2003: Raising paleoceanography. Paleoceanography 18, 91-92, doi:10.1029/2003PA000942.

Andresen, C.S., Bond, G., Kuijpers, A., Knutz, P. and Bjorck, S. 2005: Holocene climate variability at multi-decadal time-scales detected by sedimentological indicators in a shelf core NW off Iceland. Marine Geology 214, 323-38.
Andrews, J.T. 2008: The role of the Iceland Ice Sheet in sediment delivery to the North Atlantic during the late Quaternary: how important was it? Evidence from the area of Denmark Strait. Journal of Quaternary Science 23, 3-20.

Andrews, J.T. and Eberl, D.D. 2007: Quantitative mineralogy of surface sediments on the Iceland shelf, and application to down-core studies of Holocene ice-rafted sediments. Journal of Sedimentary Research 77, 469-79.

Andrews, J.T., Smith, L.M., Preston, R., Cooper, T. and Jennings, A.E. 1997: Spatial and temporal patterns of iceberg rafting (IRD) along the East Greenland margin, ca. $68 \mathrm{~N}$, over the last 14 cal.ka. Journal of Quaternary Science 12, 1-13.

Andrews, J.T., Barber, D.C. and Jennings, A.E. 1999: Errors in generating time-series and dating events at late Quaternary (radiocarbon) time-scales: examples from Baffin Bay, Labrador Sea, and East Greenland. In Clark, P.U. Webb, R.S.A. and Keigwin, L.D., editors, Mechanisms of global climate change at millennial time scales. American Geophysical Union, 23-33.

Andrews, J.T., Hardardottir, J., Stoner, J.S., Mann, M.E., Kristjansdottir, G.B. and Koc, N. 2003: Decadal to millennial-scale periodicities in North Iceland shelf sediments over the last 12,000 cal yrs: long-term North Atlantic oceanographic variability and solar forcing. Earth and Planetary Science Letters 210, 453-65.

Andrews, J.T., Jennings, A.E., Moros, M., Hillaire-Marcel, C. and Eberl, D.D. 2006: Is there a pervasive Holocene ice-rafted debris (IRD) signal in the northern North Atlantic? The answer appears to be either no, or it depends on the proxy! PAGES Newsletter 14, 7-9.

Bigg, G.R., Wadley, M.R., Stevens, D.P. and Johnson, J.A. 1996: Prediction of iceberg trajectories for the North Atlantic and Arctic Oceans. Geophysical Research Letters 23, 3587-90.

Bischof, J. 2000: Ice drift, ocean circulation and climate change. Springer-Verlag, $215 \mathrm{pp}$.

Bond, G., Kromer, B., Beer, J., Muscheler, R., Evans, M.N., Showers, W., Hoffman, S., Lotti-Bond, R., Hajdas, I. and Bonani, G. 2001: Persistent solar influence on North Atlantic climate during the Holocene. Science 294, 2130-36.

Darby, D.A. 2003: Sources of sediment found in the sea ice from the western Arctic Ocean, new insights into processes of entrainment and drift patterns. Journal of Geophysical Research 108, 13-1-13-10. doi: 10, 1111029/2002JC001350.

Darby, D.A. and Bischoff, J.F. 1996: A statistical approach to source determination of lithic and Fe oxide grains: an example from the Alpha Ridge, Arctic Ocean. Journal of Sedimentology Research 66, 599-607. 2004: A Holocene record of changing Arctic Ocean ice drift analogous to the effects of the Arctic Oscillation: Palaeoceanography 19, 1 of 9. doi: 10.1029/2003PA000961.

Dawson, A.G., Elliott, L., Mayewski, P., Lockett, P., Noone, S., Hickey, K., Holt, T., Wadhams, P. and Foster, I. 2003: LateHolocene North Atlantic climate 'seesaws', storminess changes and Greenland ice sheet (GISP2) palaeoclimates. The Holocene 13, 383-94. Dickson, R.R., Meincke, J., Malmberg, S. and Lee, A. 1988: The 'Great Salinity Anomaly' in the Northern North Atlantic 1968-1982. Progress in Oceanography 20, 103-51.

Dyke, A.S. 2004: An outline of North American deglaciation with emphasis on central and northern Canada. In Ehlers, J. and Gibbard, P.L., editors, Quaternary glaciations - extent and chronology, part II. Elsevier, 373-424.

Eberl, D.D. 2003: User guide to RockJock: a program for determining quantitative mineralogy from $x$-ray diffraction data. United States Geological Survey, Open File Report 03-78, 40 pp.

- 2004: Quantitative mineralogy of the Yukon River system: variations with reach and season, and determining sediment provenance. American Mineralogist 89, 1784-94.

Eggertsson, O. 1993: Origin of the driftwood on the coasts of Iceland: a dendrochronological study. Jokull 43, 15-32.

Eiriksson, J., Knudsen, K.L., Haflidason, H. and Henriksen, P. 2000: Late-glacial and Holocene paleoceanography of the North Iceland Shelf. Journal of Quaternary Science 15, 23-42.

Fisher, D., Dyke, A.S., Koerner, R., Bourgeois, J., Kinnard, C., Zdamowicz, C., de Vernal, A., Hillaire-Marcel, C., Savelle, J. and Rochon, A. 2006: Natural variability of Arctic sea ice over the Holocene. EOS Transactions 87, 273, 275. 
Foldvik, A., Aagaard, K. and Torresen, T. 1988: On the velocity field of the East Greenland Current. Deep-Sea Research 35, 1335-54. Hebbeln, D. 2000: Flux of ice-rafted detritus from sea ice in the Fram Strait. Deep-Sea Research II 47, 1773-90.

Jennings, A.E., Hardardottir, J., Stein, R., Ogilvie, A.E.J. and Jonsdottir, I. 2001: Oceanographic change and terrestrial human impacts in a post $1400 \mathrm{AD}$ record from the Southwest Iceland shelf. Climatic Change 48, 83-100.

Jennings, A.E., Knudsen, K.L., Hald, M., Hansen, C.V. and Andrews, J.T. 2002: A mid-Holocene shift in Arctic sea ice variability on the East Greenland shelf. The Holocene 12, 49-58.

Kerr, R.A. 2005: Atlantic climate pacemaker for millennia past, decades hence? Science 309, 41-43.

Lamb, H.H. 1979: Climatic variations and changes in the wind and ocean circulation: the Little Ice Age in the Northeast Atlantic. Quaternary Research 11, 1-20.

Lisitzin, A.P. 2002: Sea-ice and iceberg sedimentation in the ocean. Recent and past. Springer-Verlag, $563 \mathrm{pp}$.

McCarty, D.K. 2002: Quantitative mineral analysis of clay-bearing mixtures: The 'Reynolds Cup' contest. International Union of Crystallography, Newsletter 27, 12-16.

Miller, R.L. and Kahn, J.S. 1962: Statistical analysis in the geological sciences. John Wiley and Sons, $483 \mathrm{pp}$.

Moros, M., Emeis, K., Risebrobakken, B., Snowball, I., Kuijpers, A., McManus, J. and Jansen, E. 2004: Sea surface temperatures and ice rafting in the Holocene North Atlantic: climate influences on northern Europe and Greenland. Quaternary Science Reviews 23, 2113-26.

Moros, M., Andrews, J.T., Eberl, D.D. and Jansen, E. 2006: The Holocene history of drift ice in the northern North Atlantic: evidence for different spatial and temporal modes. Palaeoceanography 21, 1 of 10. doi: $10.1029 / 2005$ PA001214.

Ogilvie, A.E.J. 1996: Sea-ice conditions off the coast of Iceland A.D. 1601-1850 with special reference to part of the Maunder Minimum period (1675-1715). In Pedersen, E.S., editor, North European climate data in the latter part of the Maunder Minimum period A.D. 1675-1715. AmS-Varia 25, Arkeologisk Museum i Stavanger, 9-12. 2005: Local knowledge and travellers' tales: a selection of climatic observations in Iceland. In Caseldine, C., Russell, A., Harðardóttir, J. and Knudsen, O., editors, Iceland - modern processes and past environments. Developments in Quaternary Science 5. Elsevier, 257-87.
Ogilvie, A.E.J. and Jonsdottir, I. 2000: Sea ice, climate, and Icelandic fisheries in the eighteenth and nineteenth centuries. Arctic 53, 383-94.

Paillard, D., Labeyrie, L. and Yiou, P. 1996: Macintosh program performs time-series analysis. EOS 77, 379.

Parkinson, C.L. 2000: Recent trend reversals in Arctic sea ice extents: possible connection to the North Atlantic oscillation. Polar Geography 24, 1-12.

Smith, L.M., Miller, G.H., Otto-Bliesner, B. and Shin, S.-I. 2003: Sensitivity of the Northern Hemisphere climate system to extreme changes in Arctic sea ice. Quaternary Science Reviews 22, $645-58$

Smith, L.M., Andrews, J.T., Castaneda, I.S., Kristjansdottir, G.B., Jennings, A.E. and Sveinbjornsdottir, A.E. 2005: Temperature reconstructions for SW and $\mathrm{N}$ Iceland waters over the last $10,000 \mathrm{cal}$ yr B.P. based on $\mathrm{d} 18 \mathrm{O}$ records from planktic and benthic foraminifera. Quaternary Science Reviews 24, 1723-40.

Stoner, J.S., Jennings, A.E., Kristjansdottir, G.B., Andrews, J.T., Dunhill, G. and Hardardottir, J. 2007: A paleomagnetic approach toward refining Holocene radiocarbon based chronostratigraphies: paleoceanographic records from North Iceland (MD99-2269) and East Greenland (MD99-2322) margins. Palaeoceanography 22, 1 of 23. PA1209, doi:10:1029/2006PA001285.

Stuiver, M., Reimer, P.J., Bard, E., Beck, J.W., Hughen, K.A., Kromer, B., McCormack, F.G., v.d. Plicht, J. and Spurk, M. 1998: INTCAL98 radiocarbon age calibration $24,000-0$ cal BP. Radiocarbon 40, 1041-83.

Telford, R.J., Heegaard, E. and Birks, H.J.B. 2003: All age-depth models are wrong: but how badly? Quaternary Science Reviews $23,1-5$.

Tremblay, L.B., Mysak, L.A. and Dyke, A.S. 1997: Evidence from driftwood records for century-to-millennial scale variations of the high latitude atmospheric circulation during the Holocene. Geophysical Research Letters 24, 2027-30.

Velleman, P.F. and Hoaglin, D.C. 1981: Applications, basics, and computing of exploratory data analaysis. Duxbury, $354 \mathrm{pp}$.

Warren, C.R. 1992: Iceberg calving and the glacioclimatic record. Progress in Physical Geography 16, 253-82.

Weedon, G. 2005: Time-series analysis and cyclostratigraphy: examining stratigraphic records of environmental cycles. Cambridge University Press, 259 pp. 